\title{
America Incorporated: Movement of Assets by Companies Chartered in the United States Across the World and Back Home
}

\author{
David A. Jones
}

\begin{abstract}
This paper reports some activities of a pilot project that aimed to identify then to assess initial contributions made by selected American companies conducting business in Poland at various times since the collapse of Communism in 1991. It chronicles surveys undertaken by the author's graduate students that included administration of questionnaires with personal interviews of company managers, obstacles encountered, efforts to overcome obstacles, implications for future research, plus preliminary projections of strategies United States government officials need to adopt to maintain repatriation of corporate profits. This research raises questions whether American FDI should be presumed to be good for either America or host countries such as Poland, as well as the extent to which the American taxpayer should tolerate sequestration of assets abroad by giant Fortune-ranked corporations that were chartered in the United States. Questions arise also concerning the propriety if not the legality of large accounting and international law firms assisting and encouraging American corporations in such efforts to hide assets abroad.
\end{abstract}

Index Terms-American FDI; Corporate Taxes; Poland; Repatriation of Profits.

\section{INTRODUCTION}

Corporations chartered in the United States have been on the move in the 21 st century, seeming to flee from what their executives deem to be excessive "red tape" particularly in the form of taxation in the United States. Suddenly, however, with the inauguration as President of Donald J. Trump and approval by the Congress (entirely along party lines) of a huge 14-point reduction in corporate tax rates, companies began to repatriate profits they had longsequestered abroad in foreign tax havens ranging from Bermuda, Cayman Islands, (English) Channel Islands to Ireland and Switzerland [1]. Whether this is because of their reading President Trump's lips, urging: "Make America Great Again" or less nobly "America First" or on account of the low penalty one time "repatriated tax break" the Administration has touted rather effectively, remains to be determined [2]. Profits do seem to be flowing back to America in the billions of dollars [3].

What follows is sequentially what happened in the course of the research. This article reports on progress made by a pilot project intended to identify and assess positive and negative contribution(s), if any, made by American

Published on March 7, 2018.

D. A. Jones is with University of Warsaw's Institute of the Americas and Europe, Institute of International Relations, and Faculty of Management, Poland. (e-mail: david.jones@uw.edu) companies as they entered the Polish market following the collapse of the Communist government from 1989 to 1991. Numerous companies chartered by states of the United States opened branches in Poland and elsewhere in Europe. Initially, for them, Central and Eastern European Countries (CEEC) seemed veritably to be "Blue Ocean" territory devoid of competition domestic or international [4]. As the third decade of this most recent independence of Poland and of neighbouring CEEC bloc nations draws to a close, it is fair to enquire whether that once "Blue Ocean" stayed blue naturally or artificially (whether foreign companies held competition at bay, for example) or if the "Ocean" remained blue pigmentation at all or, alternatively, already has become a competitive "Red Ocean" [5]?

Is it attractive for American companies to stay in CEEC regions, or, put differently, is it attractive to CEEC regions to have them stay? Is it as fair as it is chic to conclude that American Foreign Direct Investment (FDI) in Poland specifically, also in Africa, Asia, or Europe generally, has been beneficial to America itself as well as to host countries? Initially, American Chamber of Commerce in Poland (AmCham) promised support for this project. As we commenced to focus incisively on the shortcomings of American FDI together with value added contributions, AmCham support diminished and then was withdrawn. Thereupon, AmCham requested American companies to stop cooperating with participants in this project, without any plausible explanation.

Apparently, some entities endeavored to commission research findings that would generate a self-fulfilling prophecy "proving" that American companies contributed to host country economies. That conclusion is unproven. University of Warsaw researchers could not deliver it ethically, nor could they disprove it. A pilot study is not expected to generate large-scale empirical findings that require an influx of funding from public or Nongovernmental (NGO) sources, or both. As but one example of much larger studies that have experienced difficulty generating concrete results of their empirical research, consider estimates by Tax Justice Institute researchers that "at least \$21 to \$32 trillion as of 2010 has been invested virtually tax free through the world's still expanding black hole of more than 80 offshore secrecy jurisdictions [6], tied specifically in too many cases to untaxed unreported earnings of accumulated offshore wealth actually held by "developing" countries within the developed world including the United States, making such "developing" countries actual lenders or equity investors instead of debtors as they pretend to be frequently [6]. Little wonder, 
consequently, that percentage of foreign ownership of United States financial assets plus United States owner-ship of foreign financial assets escalated measurably in the $21 \mathrm{st}$ century, and largely in tandem as Fig. 1 below reflects [7], further adding to the question of whether American FDI is entirely beneficial to United States or foreign host country interests, in contrast to being beneficial almost entirely to Parent Country Nations (PNNs) and Host Country Nationals (HCNs) who manage these companies. AmCham as a Nongovernmental Organisation (NGO) is tied rather heavily to embassies of the United States and to their ambassadors who serve as honorary officers, wielding clout that favours AmCham member companies ahead of other businesses.

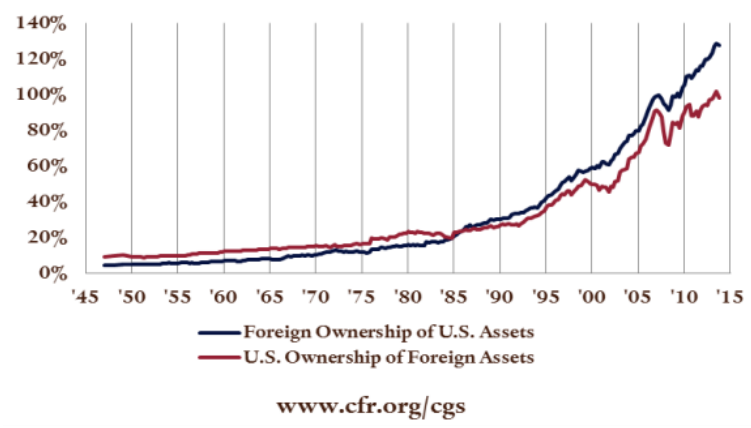

Fig. 1. U.S. Ownership of Foreign Assets Increased in Tandem with Foreign Ownership of U.S. Assets, 1945 to 2015 [7].

American companies that include but are not limited to America's largest banking institutions tend to scope foreign business environments to determine what local businesses they can displace, as Fig. 2 below evidences. To its credit, virtually along amongst the 10 largest banking institutions in the United States, Bank of America did not invest in FinTech in 2017 [8]. This practice is not limited to banking or other financial institutions. In retailing, WalMart is notorious for having forced out of business many "Ma" and "Pa" department stores that once proliferated on Main Streets across the United States, by undercutting prices until this competition was compelled to close, then raising prices. It tried to replicate that paradigm in the first decade of the 21 st century in Germany by attempting to implement the same notorious design, causing WalMart to be rebuffed by German competitor retailers and consumers alike, causing it to withdraw therefrom with heavy financial losses [9].

Throughout the research project described herein, a valid question emerged whether the mere presence in Europe or Asia of an American corporation is an asset, a liability, or neither. Some American companies may be assets because they bring to a foreign environment a part of America itself, such as entertainment in cinema, music or sports. Or, American companies may simply enter European or Asian marketplaces disruptively by causing unfair competition, stifling local businesses, as in the example of WalMart's attempt to penetrate Germany's retail market, without any significant added value to consumers as customers, at least in the long term. On the flip side of the coin, American firms in foreign countries may not generate shareholder value or tax revenues back home, rendering deployment in foreign countries a "lose-lose" scenario at home and abroad. Then the question arises, what are they doing in any given foreign country? Do they provide employment to the local workforce beyond what those workers could find in domestic companies, or higher salaries to HCN managers?

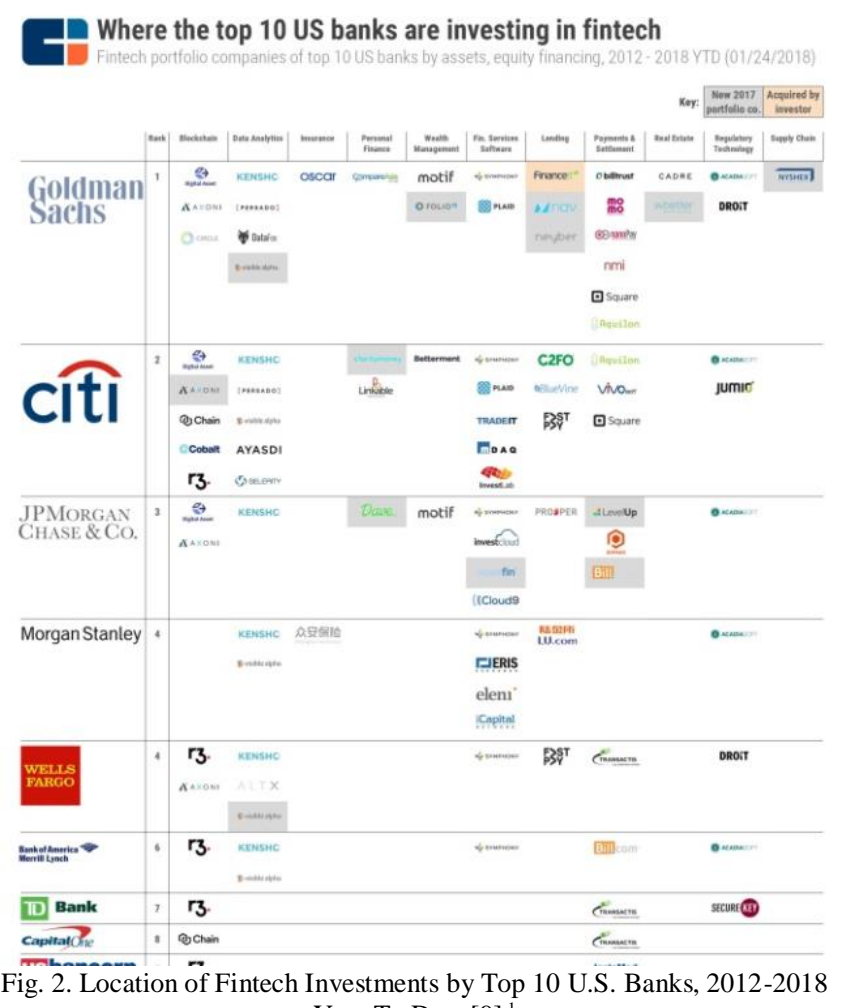
Year To Date [9]

\section{PROCEDURES}

Faculty at the University of Warsaw (UW) Institute of The Americas and Europe (IAiE) asked the author as a senior faculty member to design then implement a pilot study to determine the impact and value, if any, that American companies doing business in Poland since 1991 have exerted upon the United States and the Republic of Poland. As a courtesy, initially the author connected with officials at the United States Embassy in Warsaw to gather their thoughts on the matter, harvest some insights. Soon one embassy official referred the author to managers at the American Chamber of Commerce (AmCham) in Poland. Following a series of brief discussions, they invited the author and his UW graduate students to join them in the implementation of their vision for a parallel study that would survey some 200 American corporations with subsidiaries in Poland that are AmCham members.

AmCham proposed 30 companies to be sampled purposefully. This project was designed to take 12 months to complete. It began in February 2017 and finished in February 2018, almost exactly one year after it commenced. In some ways, it exhibits what can go wrong with partnerships as well as research, as well as what can be derived from quantitative or qualitative studies even when progress does not move smoothly.

Questionnaires were constructed to survey representatives of sampled American companies before they would be

1. "Gray boxes indicate that the company is a new addition (since the start of 2017) to that investor's portfolio. Light orange boxes indicate that the investor acquired that portfolio company (itself)." 
interviewed, with Interview Protocols designed to follow up on Questionnaire responses. Initially, all corporate representatives were cooperative in answering Questionnaires, granting hour long interviews. An example was Microsoft. Some companies rescheduled interview dates, times or locations, as was expected.

Interviews were scheduled then done by interviewers working in pairs, mostly one female with one male. Questionnaires were sent by email to company representatives identified as prospective respondents ahead of each interview, ideally 10 days or more in advance. Answers to survey questions were followed-up during interviews, functioning as tools used to provoke open-ended discussion and also to verify answers. Each interview that occurred ended cordially, usually with the interviewee offering proactively to answer subsequent enquiries by telephone. Suddenly cooperation stopped!

Soon after the middle of our Spring Term 2017, AmCham managers commenced to voice discontent with multiple facets of the project. They felt it was proceeding too slowly with more focus than necessary upon qualitative instead of quantitative variables, complained of student quality (many, not all, of our M.A. students were our B.A. students earlier in a programme that has a six to one rejection rate or higher, comparable to Ivy or Russell League universities), chided participants who were absent from classes (the university permits three per term). At the $14^{\text {th }}$ and next to last class, AmCham announced its intention abruptly to withdraw cooperation. More deleteriously, it sent communications requesting its members not to grant further interviews with our team. What astonished our team the most is that all American companies conducting business in Poland complied with AmCham's request as lemmings and abruptly stopped talking with us. A few respondents from companies that are not American ignored AmCham and gave us interviews. No one copied us on or even showed us AmCham's letter. AmCham promised to do so itself, but reneged.

We undertook this project as part of a 12 month two semester indivisible course., so we had little choice but to proceed without AmCham cooperation, using data available to us. That included results of interviews and answers to survey questions received from respondents whom our team interviewed before AmCham withdrew, along with answers that had been provided by respondents scheduled to be interviewed but who aborted interview at AmCham's behest. Various strategies for project completion were discussed, ranging from approaching home office executives in the United States to interviewing managers of foreign subsidiaries from countries other than the United States operating in Poland.

Most high level managers of American companies currently operating in Poland are host country nationals (HCNs) (Polish), so we decided we would gain little by going over their heads to their supervisors in the United States. Also, some mid-level Polish managers told our team that, in reality, most decisions involving Fortune-ranked United States subsidiaries in Poland are made by Polish managers in Poland, rendering the parent country nationals (PCNs) in America oblivious to details of Polish operations. We encountered some Polish and third country nationals
(TCNs) affiliated with subsidiaries of non-American companies in Poland who, as anticipated, seemed only too glad to offer their insights, mainly negative, concerning American firms in Poland. Mainly, these respondents pointed to several international accounting and law firms at which American companies seek and from which they receive advice on tax avoidance, steadfastly refusing to identify such firms by name. This corroborates the literature that suggests United States financial institutions rank second after Switzerland in evidencing the most secrecy in the world of financial institutions [10], as the list in Table I below illuminates. In fact, the United States ranks immediately above the Cayman Islands and well above Guernsey, notorious tax shelters. Poland is listed in $51^{\text {st }}$ position amongst the 112 countries surveyed, making Poland five positions higher than the median, or roughly typical of the environment globally.

\begin{tabular}{ll}
\multicolumn{2}{c}{ TABLE I: SECRECY RANKING BY COUNTRY [10] } \\
\hline \hline 1. & Switzerland \\
2. & USA \\
3. & Cayman Islands ${ }^{2}$ \\
4. & Hong Kong \\
5. & Singapore \\
6. & Luxembourg \\
7. & Germany \\
8. & Taiwan \\
9. & United Arab Emirates (Dubai) \\
10. & Guernsey \\
11. & Lebanon \\
12. & Panama \\
13. & Japan \\
14. & Netherlands \\
15. & Thailand \\
51. & Poland \\
\hline \hline
\end{tabular}

Members of our team obtained some public records available in Warsaw to reflect corporate earnings and taxation reported by subsidiary firms owned or controlled by United States corporations. Requirements for this data are similar to what American parent companies must file periodically with the United States Securities Exchange Commission (SEC). Once we noticed that Polish SEC filings are incomplete or late, we abandoned this route, because data retrieved is inconsistent across companies, rendering comparisons difficult to make, impossible to make accurately.

Toward the end of this project, some of the participants were able to interview United States embassy officials. That proved to be productive, because it enabled us to gain insight into American government perception of the quality and purpose of American FDI in Poland, both historically and at present. An embassy official praised Google and Microsoft for the "incubator" programmes each installed in Poland, aimed at nurturing start-up Polish businesses.

\footnotetext{
${ }^{2}$ British overseas territory or crown dependency. If Britain's network were aggregated, it would be on top
} 


\section{DISCUSSION}

American companies have come to Poland at different times for various reasons. In the early period between 1991 and the end of the $20^{\text {th }}$ century, Poland presented what has since become known as "Blue Ocean" or an environment largely devoid of competition in the largely prevailing "Red Ocean" terrain of North America and Western Europe [5], this contrast having been drawn brilliantly by Kim and Mauborgne in the $21^{\text {st }}$ century. American companies that invested in Poland then stayed in Poland forecasted accurately that Poland would grow to become among the "strongest performers in emerging Europe, and one of the most resilient economies to the euro-crisis", in part at least because of Polish domestic consumer spending as the Polish economy has kept growing ahead of most other European economies in Eastern or Western Europe [11].

Defense industries attract investment of course, due to Poland's location on Europe's Eastern frontier, that explains the continuous presence of defense software provider Raytheon and F-16 manufacturer General Dynamics. Poland's future horizon seems to be bright, as the Polish embassy website in Washington illuminated: "Poland faces a great opportunity to build a strong energy sector following the USA where the share of shale gas in the overall gas supply rocketed from $1 \%$ in 2000 to $20 \%$ now, and it is believed for further grow reaching as much as $50 \%$ in 2035 " [11]. Poland's low-tech coal industry has kept domestic electricity prices low over the past three decades, also, making the country attractive to high-tech product manufacturers.

American FDI gave Poland the boost it required in the decade following 1991. Since that time, American FDI has stayed constant at about USD 20 Billion as other European countries nudged American FDI in Poland down to fifth position by 2012 then entirely out of the top ten list by 2015 [12], as is evident from Table II below that depicts Netherlands, United Kingdom, and Germany as Poland's top foreign investors, with each holding a stake of about 20 percent.

\begin{tabular}{lc} 
TABLE II: POLAND'S INWARD FDI, BY COUNTRY, 2015 [12] \\
\hline \hline The Netherlands & 23.6 \\
UK & 20.9 \\
Germany & 19.4 \\
Spain & 8.0 \\
Austria & 6.2 \\
Luxembourg & 6.0 \\
Sweden & 5.3 \\
Cyprus & 5.3 \\
Belgium & 4.0 \\
Switzerland & 3.4 \\
\hline \hline
\end{tabular}

Alphabet (Google) and Microsoft have contributed positively to the Polish economy in the form of "inspiration industries" by founding "incubator" and "accelerator" centres to nurture local start-up businesses in Warsaw, Krakow and Poznan. That said, some Polish entrepreneurs have criticised American inspiration industries along with some of their European counterparts, for reasons that vary but include too much "red tape," too high default rates by recipients, excessive shares of start-up companies taken by incubators, accelerators, or their principal managers, or usurpation of start-up ideas by larger local companies that stalk then jump ahead of smaller entities in start-up markets [13].

Forecasts are being made that Central and Eastern Europe, with Poland in the lead, stand to become key locations as American incubators and accelerators begin to flourish in Europe, rivaling the United Kingdom and Germany [14]. Hard evidence for this is in the form of Google's "Warsaw Campus" that appears to invite nearly every variety of entrepreneur to stop by and "apply" to join [15]. Time will tell whether "inspiration centres" funded by American tech giants will succeed sustainably in the CEEC region or be challenged successfully either by local counterparts or global competitors from third countries. In 2017, Samsung opened an incubator in Warsaw [16].

When attempting to assess the internal strengths against weaknesses, or the external opportunities compared to threats, posed by FDI generally, especially in context of rapidly rising economies such as Poland's, it is complicated to reach a viable conclusion on the issue of whether benefits outweigh costs and, if they do, for whom. Shareholder value to the parent companies is the factor pointed to most often in measuring success or failure of any corporate investment. In this project, we were unable to obtain Data reflecting a fair Return On Investment (ROI) for any company studied. Participants in this study who were all Polish except for the author, were surprised that most managers of American subsidiaries in Poland have been Polish, except for the first few years after 1991, recognizing that interviewees reported that key managers of almost every foreign-owned company in Poland are PCNs, except at American concerns where they have been and where they remain $\mathrm{HCNs}$, functionally becoming Polish companies in all but name. Even more astonishing is the fact that the U.S. Ambassador to Poland is honorary chair of the AmCham Poland board of directors [17].

\section{CONCLUSION}

If this research project has proven anything, that is how difficult it is for academic teams to pair with nongovernmental organizations (NGOs). Expectations vary, not just in what results will be obtained or when, but concern over research methods, ethics, independence of investigators, plus the immense value of "serendipity" or collateral knowledge beyond that initially sought. It highlights the value of all prospective respondents being drawn from random samples instead of purposefully, with the sampling frame being selected by the research team itself, if only because when a partner such as AmCham provides access to respondents, as easily as it provided that access it can withdraw it.

In 1991, then for a decade thereafter, Poland seemed to American companies to be a veritable panacea as a very deep "Blue Ocean" devoid of much competition for American products that Polish consumers had craved for so long. That has changed, evidenced by the entry of FDI from most major European countries that is beginning to dwarf American investment in Poland, outside of defense industries. A similar paradigm seems to be emerging with 
respect to recent incubator and accelerator campuses launched by American companies. Polish entrepreneurs show signs of apprehension as they view American corporate motives. Once more, "Blue Ocean" is turning into a "Red Ocean" not only in actual competition to attract and retain consumers, but also in nurturing the entrepreneurs of the future. It is a common syllogism from one country to another in the post-communist world: find a "seed" partner, America in Poland's case, then when that seed germinates, disloyally turn to partners elsewhere or everywhere.

\section{ACKNOWLEDGMENT}

Professor Jones wishes to acknowledge participants in Learning by Research, Spring Term 2017 and Fall Term 2017, as follow: Hubert P. Gadowski, Filip M. Gersz, Filip P. Janas, Natalia S. Kazimierczuk, Wojciech J. Kosmala, Michał F. Kuźnik, Natalia Z. Lewczak, Lena Osińska, Kamila Siemieńczuk, Małgorzata A. Zacheja.

\section{REFERENCES}

[1] H. Gural. 2017. "Offshore Corporate Tax Loopholes," Americans for Tax Fairness. https://americansfortaxfairness.org/files/9-ATFOffshore-Corporate-Tax-Loopholes-fact-sheet.pdf See also, L. Summers. 2017. "One last time on whom corporate tax cuts benefit," Financial Times. 02 Nov. https://www.ft.com/content/5a362cb6-c2af3138-bf5d-f1c92b695378

[2] "The Growth Effects of Corporate Tax Reform and Implications for Wages." Washington, D.C.: October 2017, U.S. Council of Economic Advisers.

https://www.whitehouse.gov/sites/whitehouse.gov/files/images/Corpo rate\%20Tax\%20Reform\%20and\%20Growth\%20Final.pdf

[3] K.P. Erb. 2018. “Apple Says It Will Bring Cash Back To US, Pay \$38 Billion In Repatriation Tax,” Forbes. 17 Jan.https://www.forbes.com/sites/kellyphillipserb/2018/01/17/applesays-it-will-bring-cash-back-to-us-pay-38-billion-in-repatriationtax/\#c1f70b922226 See also, M. Feldstein. 2017. "The International Consequences of US Tax Reform,” Project-Syndicate.org. 27 Sep. https://www.project-syndicate.org/commentary/united-states-taxreform-international-impact-by-martin-feldstein-201709? barrier=accessreg

[4] W.C. Kim \& R. Mauborgne. 2017. Blue Ocean Shift: Beyond Competing: Proven Steps to Inspire Confidence and Seize New Growth. London: Macmillan Hachette Books. See also, Ibid. 2017. Blue Ocean Leadership. Cambridge, MA: Harvard Business Review Press.

[5] W.C. Kim \& R. Mauborgne. 2017. Red Ocean Traps. Cambridge, MA: Harvard Business Review Press. See also, I. Lainos. 2011. Red Ocean vs. Blue Ocean Strategies. Athens: University of Piraeus Press, 68-77.
[6] Henry, James S. 2012. "The Price of Offshore Revisited: New Estimates for 'Missing' Global Private Wealth, Income, Inequality, and Lost Taxes," Tax Justice Network.http://www.taxjustice.net/cms/upload/pdf/Price_of_Offshore _Revisited_120722.pdf

[7] Walker, Dinah. 2015. "Quarterly Update: Foreign Ownership of U.S. Assets," Federal Reserve Bureau of Economic Analysis \& Greenberg Center for Geoeconomic Studies through Council on Foreign Relations. 21 Jan. https://www.cfr.org/report/quarterly-updateforeign-ownership-us-assets

[8] "Where Top US Banks Are Betting On Fintech," CBInsights Research Briefs. 01 February 2018.

https://www.cbinsights.com/research/fintec- investments-top-us banks/?utm_source $=\mathrm{CB}+$ Insights + Newsletter\&utm_campaign $=\mathrm{aa} 617$ 392f7-

Top_Research Briefs 02_10_2018\&utm_medium=email\&utm term $=0 \_9 d c 0513989$-aa617392f7-90121066

[9] D. John, et al. 2008. "Wal-Mart's 'Think Global, Act Local': Can 'Americanisation' Have Its Way"," IBS Research Center (Ref. No. 308-215-1).

[10] Tax Justice Network. 2018. "Financial Secrecy Index: 2018 Results," taxjustice.net. https://financialsecrecyindex.com/introduction/fsi-2018-results Also

[11] R.J. Guttman \& J. Kozenkow. 2012. "Poland: A Profitable Place to Invest," TransAtlantic Magazine. 03 Oct. http://transatlanticmagazine.com/poland-a-profitable-place-to-invest/

[12] Santander. 2018. "Poland: Foreign Investment." Santander Trade Portal. https://en.portal.santandertrade.com/establishoverseas/poland/foreign-investment

[13] M. van Blommestein. 2012. "Is Poland the Best Place to Start Your Start-up?" Central European Processing. 16 Nov. http://www.zdnet.com/article/is-poland-the-best-place-to-start-yourstart-up/

[14] S.B. Guia. 2017. "Poland and Eastern Europe heating up as technology hotspots," The Sociable. 27 Sep. https://sociable.co/technology/eastern-europe-heatingup-techhotspot//

[15] “Campus Warsaw: Google's Space for Entrepreneurs," Google Space. https://www.campus.co/warsaw/en/about/

[16] "Samsung Incubator: Helping Digitize Poland by Supporting Startups," Samsung Newsroom. 28 April 2017.

https://news.samsung.com/global/samsung-incubator-helpingdigitize-poland-by-supporting-start-ups.

[17] American Chamber of Commerce in Poland, Board of Directors. http://amcham.pl/about-us/board-of-directors

David A. Jones is Professor of International Law, Management, and Foreign Policy at University of Warsaw's Institute of The Americas and Europe, Institute of International Relations, and Faculty of Management. He has headed American Studies Center's United States Law Program and Advanced Track M.A. Program. He is a senior graduate faculty member at Norwich University, Northfield, Vermont, the Military Academy of the State of Vermont, where he has offered Global Corporate Diplomacy (capstone course) and Intercultural Management in the International System for over a decade. Email: david.jones@uw.edu.pl. 